\title{
Immunoexpression of vascular endothelial growth factor and $B$-cell lymphoma 2 in the uterine tissue of rats treated with melatonin in the estrus phase ${ }^{1}$
}

\author{
Neval Yaman Görük', Engin Deveci"
}

'MD, Department of Obstetrics and Gynecology, Memorial Hospital, Diyarbakır, Turkey. Conception and design of the study, technical procedures, manuscript writing, critical revision.

"PhD, Professor, Department of Histology and Embryology, Faculty of Medicine, Dicle University, Diyarbakır, Turkey. Conception and design of the study, technical procedures, histological examinations, manuscript writing, critical revision.

\begin{abstract}
Purpose: To investigate the effect of melatonin on uterine tissue in the ovariectomized rat model.

Methods: Fourty Wistar albino rats were divided into four groups for histologic and immunohistochemical examination. The rats were first numbered randomly and then randomly divided into 4 equal groups: control (group 1), torsion (group 2), torsion+detorsion (group 3) and torsion+detorsion+melatonin (group 4) groups. In addition, four Wistar albino rats were used for western blot analysis in each group. And also, malondialdehyde (MDA) levels were measured biochemically in all rats.

Results: The histopathological examination of the uterine tissue in rats ovarectomized showed a degeneration in uterine glands, dilation of blood vessels in the internal layer with a thrombosis and bleeding, abnormal nucleuses and vacuolated cytoplasm above and below the nucleus. In torsion group, the apoptotic cells increased in luminal epithelium and gland cells. In the melatonin group showed that the $\mathrm{Bcl} 2$ negative effect on the uterine epithelium and did not lead to apoptotic cells.

Conclusion: The increase in vascular endothelial growth factor expression resulted in the rearrangement of endothelial cell growth and the induction of angiogenesis.

Key words: Ovary. Uterus. Melatonin. Lymphoma, B-Cell. Vascular Endothelial Growth Factor A. Rats.
\end{abstract}




\section{- Introduction}

Melatonin hormone secretion is produced by norepinephrine (NE)-driven pulses released by the intraparenchymal nerve fibers. This NE-releasing activity and therefore the working principle of the pineal gland is activated in the dark and inhibited by light. The dark-light conditions are transmitted to the suprachiasmatic nucleus, which is blocked by light by the eyes and actuated in the dark as a result of the absence of such an obstacle $e^{1-4}$. Melatonin and its metabolites are powerful free radical scavengers and broad spectrum antioxidants. Up to now, It has been investigated for the effects of melatonin on endometriosis in rats or mice in terms of expression of Bcl-2 and VEGF in recent years ${ }^{5-11}$. Studies in animals and human have shown a significant effect of melatonin on cell death in different tissues and systems, including the urogenital system. It appears that melatonin plays a modulatory role in apoptosis and may offer both pro-apoptotic and anti-apoptotic actions ${ }^{12-15}$. Several studies have indicated that antioxidant defences may be altered in endometriosis, as suggested by the aberrant expression of endometrial antioxidant enzymes and lower levels of the antioxidant vitamin $E$ in peritoneal fluid ${ }^{16,17}$. Melatonin plays also a role in neuroendocrine regulation, the increase of immunity, the neutralization of free radicals, the reduction of angiogenesis, the increase of apoptosis, studies on animals and humans demonstrating that melatonin has important oncostatic properties. Blood melatonin levels are reversely correlated with the tumor proliferation index in patients with endometrial cancer ${ }^{18}$. The emphasis of immunological elements has also shown that melatonin can inhibit apoptosis by inducing the release of cytokines such as interleukin- ${ }^{19}$. It is known that melatonin interacts with nuclear receptors. This interaction has been shown to alter the gene expression of the inducers or inhibitors of apoptosis. In several studies, it was reported that the effects of melatonin on uterine structure and function ${ }^{20-22}$. Dair et $a .^{23}$ have reported that melatonin affects some morphological properties of the rat endometrium, particularly on the success rate of embryo implantation. It is explained that the underlying mechanisms of this effect may develop in two different ways. It has been reported that either directly acting on the melatonin receptors or indirectly due to a disorder of ovarian steroids. Similarly, melatonin has been reported to be effective on adrenal cortex in pinealectomized rats, especially in fascicular and reticular regions. In the pinealectomized group, VEGF-A expression was higher than the other groups. These results have revealed the increase in percentage of apoptosis ${ }^{24}$. Soares et al..$^{25}$ have reached the conclusion that the increase in the number and activity of interstitial cells may be a consequence of hormonal disturbances after pinealectomy and that it is responsible for increasing estrogen blood levels and delaying the transition to metaphores. Romeu et al. ${ }^{26}$ have founded that pinealectomized samples presented signals of proliferation on ovarian surface epithelium and interstitial cells as well as high expressions of proliferating cell nuclear antigen and VEGF in rats. And, they concluded that melatonin may an important role in proliferation in ovarian structures and increase the number of luteal bodies as well as the levels of progesterone receptor.

Vascular endothelial growth factor is a multifunctional cytokine that stimulates angiogenesis and increases microvascular permeability through binding to specific receptors expressed on vascular endothelial cells ${ }^{27,28}$. The $\mathrm{Bcl}-2$ gene encodes a membrane protein localized to the nuclear membrane, the inner surface of mitochondria, and the endoplasmic reticulum ${ }^{29}$. It is the important gene of the $\mathrm{BCl}-2$ family and has been shown to be an inhibitor of apoptosis ${ }^{30,31}$.

The purpose of this study was to 
evaluate immunoexpression of vascular endothelial growth factor and $\mathrm{Bcl}-2$ in the endometrium of rats treated with melatonin in the estrus phase.

\section{- Methods}

All animal experiments and the consequent care and healing of the animals utilized as a part of this investigation were in strict understanding with the National Institutes of Health (NIH Publications No. 8023, revised 1978) rules for animal care. All procedures performed in this experiment were approved by the Ethics Committee for the Treatment of Experimental Animals (University of Dicle, Faculty of Medicine, Turkey, Protocol number: 2017-12).

Totally fifty-six Wistar albino rats (180- 210 g, 12 weeks old) were kept up under $22 \pm 1^{\circ} \mathrm{C}$ and $12 \mathrm{hrs}$ light/gray cycles with ad libitum access to standard pelleted nourishment and water during 7 days. All rats at the end of experiment were healthy and no difference in food/water consumption and body weight gain between experimental and control rats were observed. Totally fifty rats were numbered and then divided into 4 equal groups randomly $(n=10)$ : Control (Group 1), Torsion (Group 2), Torsion+Detorsion (Group 3) and Torsion+Detorsion+Melatonin (Group 4) groups for histologic and immunohistochemical examination. In addition, four rats in each group were used for Western blot analysis. Following acclimation, the stage of the estrus phase of the rats was evaluated by performing daily vaginal smears. The rats determined to be in estrous were weighed and prepared for the surgical procedure. Each rat was administered intramuscular ketamine hydrochloride $(50 \mathrm{mg} / \mathrm{kg}$ Ketamin hydroxide) and xylazine hydrochloride $(10 \mathrm{mg} / \mathrm{kg}$ Rompun; Bayer, Istanbul, Turkey) for anesthesia ${ }^{32}$. $1 \mathrm{ml}$ preoperative blood sample was drawn from the tail of each rat for the measurement of hormone levels. In all of the groups, a midline abdominal incision of 2,5 cm (laparotomy) was performed under sterile conditions. In the control group, the uterine horns and adnexa were observed for 1 minute. In the torsion+detorsion group, bilateral adnexal torsion (3-hour ischemia) was induced. The adnexal torsion procedure was carried out as follows: the adnexal was rotated $360^{\circ}$ in a clockwise direction, including tubal and ovarian vessels and then fixed to the abdominal wall. In the detorsion group, detorsion (3-hour reperfusion) was performed following the 3-hour torsion ${ }^{32}$. The uterus tissues were fixed in $10 \%$ neutral buffered formalin solution for $24 \mathrm{~h}$, dehydrated, cleared and embedded in paraffin as usual. Serial tissue sections at a thickness of 4-5 $\mu \mathrm{m}$ were cut using the microtome for the histopathological examinations.

\section{Immunohistochemical technique}

Uterine tissue were brought to distilled water and washed in $3 \times 5$ min Phosphate Buffered Saline (PBS). Catalog number 10010023, Thermo Fischer Scientific Fremont, CA, USA. Antigen retrieval was done in microwave (Bosch, 700 watt) for $3 \mathrm{~min} \times 90^{\circ} \mathrm{C}$. They were subjected to a heating process in a microwave oven at 700 watts in a citrate buffer $(\mathrm{pH} 6)$ solution for proteolysis. Sections were washed in $3 \times 5$ min PBS and incubated with hydrogen peroxide [K-40677109,64271 Hydrogen peroxide $\left(\mathrm{H}_{2} \mathrm{O}_{2}\right)$ Dortmudt+Germany, MERCK] (3ml \%30 Hydrogen peroxide $\left(\mathrm{H}_{2} \mathrm{O}_{2}\right)$ $+27 \mathrm{ml}$ methanol) for $20 \mathrm{~min}$. Sections were washed in $3 \times 5$ min PBS min and blocked with Ultra V Block (lot: PHL150128, Thermo Fischer, Fremont, CA, USA) for $8 \mathrm{~min}$. After draining, primary antibodies were directly applied to sections distinctly (Vascular Endothelial Growht Factor (VEGF), 1:100, lot\#MA5-12184, Thermo Fischer, Fremont, CA, USA; B cell lymphoma-2 (Bcl-2), 1:100, lot\#MA5-11757, Thermo Fischer, Fremont, CA, USA) for 14 
min. After washing with PBS, Streptavidin Peroxidase (lot: PHL150128, Thermo Fischer, Fremont, CA, USA) was applied to sections for $15 \mathrm{~min}$. Sections were washed in $3 \times 5 \mathrm{~min}$ PBS and Diaminobenzidine (DAB, Invitrogen, Carlsbad, lot: HD36221, Thermo Fischer, Fremont, CA, USA) were applied to sections up to $10 \mathrm{~min}$. Slides showing reaction was stopped in PBS. Counter staining was done with Harris's Haematoxylin for $45 \mathrm{sec}$, dehydrated through ascending alcohol and cleared in xylene (Product Number: HHS32 SIGMA, Hematoxylin Solution, Harris Modified, Sigma-Aldrich, 3050 Spruce Street, Saint Louis, MO 63103, USA). Slides were mounted with Entellan (lot: 107961, Sigma-Aldrich, St. Louis, MO, United States) and examined under Olympus $\mathrm{BH}-2$ light microscopy.

\section{Western blot analysis}

The protein expression levels of VEGF and $\mathrm{BCl}-2$ were examined by Western blotting. Briefly, proteins were extracted from uterine tissue, separated on 10-12\% SDS-PAGE gels (40 $\mathrm{mg} /$ lane) and then transferred to nitrocellulose membrane (Bio-Rad, Hercules, CA). Four uterine tissue were blocked with $5 \%$ non-fat milk in TBST buffer $(10 \mathrm{mmol} / \mathrm{L}$ Tris- $\mathrm{HCl}, 0.15 \mathrm{~mol} / \mathrm{L}$ $\mathrm{NaCl}$, and $0.05 \%$ Tween 20, $\mathrm{pH}$ 7.1) for $2 \mathrm{~h}$ and incubated with primary antibodies overnight at $4 \mathrm{C}$ in all groups ${ }^{33}$. Primary antibodies used here were monoclonal mouse antibodies against VEGF (1:100, lot\#MA5-12184, Thermo Fischer, Fremont, CA, USA), and Bcl-2 (1:1000 dilution; Cell Signaling Technology, Boston, MA). After extensive washing with TBST buffer, the blotted membranes were then incubated for $1 \mathrm{~h}$ at room temperature with an HRPconjugated secondary antibody directed against rabbit IgG (1:2,000; Cell Signaling). The proteins were detected using an enhanced chemiluminescence system (ECL kit, Pierce Biotechnology, Beijing, China) and captured on light sensitive X-ray film (AGFA, Belgium).
Optical densities were detected using ImageJ software. $\beta$-actin was used as the loading control (Figure 1).

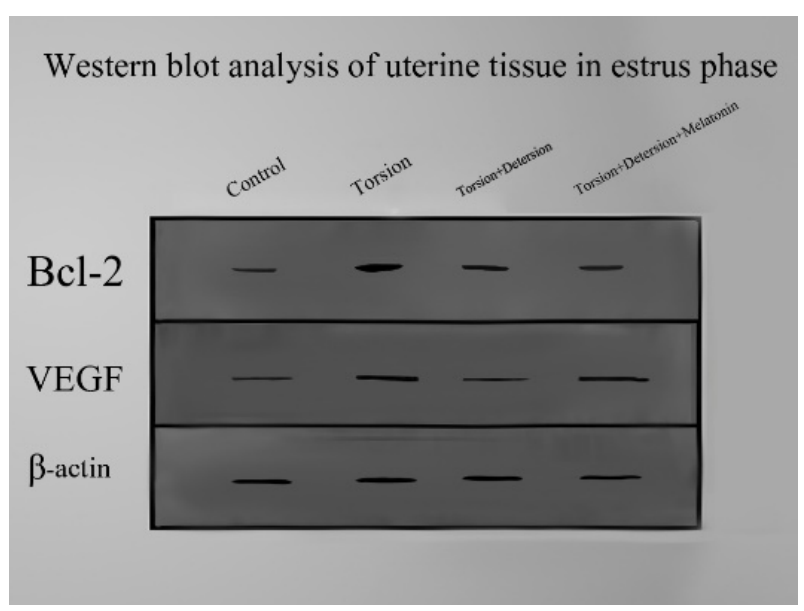

Figure 1 - The expression of $\mathrm{Bcl}-2$ and VEGF on uterine tissue was seen in estrus phase. Equal amounts of total proteins were run on the gel and analysed by Western Blotting using anti-Bcl-2, antiVEGF and anti- $\beta$-actin antibodies. $\beta$-actin was used as a loading control $(n=4)$.

\section{Analysis of MDA in rat tissues}

Malondialdehyde levels (MDA) determine levels of deterioration of lipid peroxidation mechanism. MDA is usually measured by derivation with thiobarbituric acid to give a red compound with an absorption maximum at $532 \mathrm{~nm}$. The reaction was performed at $\mathrm{pH} 2-3$ and $900^{\circ} \mathrm{C}$ for 15 min. The sample was mixed with two volumes of cold $10 \%(\mathrm{w} / \mathrm{v})$ trichloroacetic acid to precipitate the protein. The precipitate was pelleted by centrifugation and a portion of the supernatant was reacted with an equal volume of $0.67 \%(w / v)$ TBA in a boiling water bath for 10 minutes. Ovarian tissue samples were homogenized with super cold $150 \mathrm{mMKCl}$ for the assurance of MDA levels. After cooling, the absorbance was read at $532 \mathrm{~nm}$. The MDA levels were tested and the outcomes are expressed as nmol MDA/g tissue (Table 1$)^{34}$. 


\section{Statistical analysis}

In this study, descriptive statistical average, the standard error values are given with standard deviations and averages. The normal distribution assumption KolmogorovSmirnow test fit of the data, while the homogeneity was examined by Levene test. The comparison of the average Intergroup One-way analysis of variance (ANOVA) test was used. Intergroup for multiple comparisons test, Dunnett and Tukey HSD tests were used. All statistical tests used is the $95 \%$ confidence interval; $p$ value of $<0.05$ were considered statistically significant.

\section{Results}

\section{Biochemical findings}

MDA levels were compared in control and experimental groups. The comparison of all groups with each other in terms of MDA (tissue and plasma) was statistically significant (Table 1).

Table 1 - MDA concentrations in all groups.

\begin{tabular}{|c|c|c|}
\hline Groups & $\begin{array}{l}\text { Ovarian tissue } \\
\text { (nmol/mg) (mean } \pm S D)\end{array}$ & $\begin{array}{l}\text { Plasma } \\
\text { (nmol/mL) (mean } \pm S D)\end{array}$ \\
\hline (1) Control & $10.05 \pm 0.6$ & $12.25 \pm 2.9$ \\
\hline (2) Torsion & $11.08 \pm 0.3^{*}$ & $13.24 \pm 3.2 * *$ \\
\hline (3) Torsion+Detorsion & $11.84 \pm 0.2^{*}$ & $13.92 \pm 3.7^{* *}$ \\
\hline (4) Torsion+Detorsion+Melatonin & $10.45 \pm 0.4^{*}$ & $12.82 \pm 1.4^{* *}$ \\
\hline
\end{tabular}

Data are expressed as the mean \pm standard deviation. ${ }^{*} \mathrm{p}<0.05 ;{ }^{*} \mathrm{p}<0.01$.

Groups were compared in terms of length of the uterine epithelium in all groups (Table 2). The average length in parameters showed statistically significant difference $\left(\mathrm{F}=38.847,{ }^{*} \mathrm{P}<0.001\right)$.

Histomorphometric analysis

In our study, we observed that the length of epithelium and the diameter of uterinal glands were decreased bilaterally in torsion group (Tables 2 and 3). The length of the uterine luminal epithelium and diameter of the uterine glands in melatonin administrated group were similiar as in control group.

Table 2 - The length of the uterine luminal epithelium.

\begin{tabular}{llllll} 
Groups & $n$ & Mean & Std. deviation & Std.Error & $\begin{array}{l}\text { Different }(P<0.05) \\
\text { from groups } n \boldsymbol{r}\end{array}$ \\
\hline (1) Control & 10 & 8.4650 & 1.28268 & .40562 & $(2),(3),(4)^{* *}$ \\
(2) Torsion & 10 & $5.2960^{*}$ & 0.71481 & .22604 & $(1),(3),(4)^{* *}$ \\
(3) Torsion+Detorsion & 10 & $4.5120^{*}$ & 1.19105 & .37664 & $(1),(2),(4)^{* *}$ \\
(4) Torsion+Detorsion+Melatonin & 10 & $8.0720^{*}$ & 0.66518 & .21035 & $(1),(2),(3)^{* *}$ \\
\hline
\end{tabular}

Data are expressed as the mean \pm standard deviation. ${ }^{*} p<0.001 ; * * p<0.05$.

In terms of the average diameter of uterine gland parameter has changed in a statistically significant manner $(F=29.186, * \mathrm{P}$
$<0.001)$. Multiple comparison values between the groups is given in Table 3. 
Table 3 - The diameter of the uterine glands.

\begin{tabular}{llllll} 
Groups & $\boldsymbol{n}$ & Mean & Std. deviation & Std.Error & $\begin{array}{l}\text { Different }(\mathbf{P < 0 . 0 5 )} \\
\text { from groups } n \boldsymbol{r}\end{array}$ \\
\hline (1) Control & 10 & 38.6530 & 4.89585 & 1.54820 & $(2),(3),(4)^{* *}$ \\
(2) Torsion & 10 & $26.5180^{*}$ & 2.21264 & .69970 & $(1),(3),(4)^{* *}$ \\
(3) Torsion+Detorsion & 10 & $34.4230^{*}$ & 2.91304 & .92118 & $(1),(2),(4)^{* *}$ \\
(4) Torsion+Detorsion+Melatonin & 10 & $37.2000^{*}$ & 1.67398 & .52936 & $(1),(2),(3)^{* *}$ \\
\hline
\end{tabular}

Data are expressed as the mean \pm standard deviation. ${ }^{*} p<0.001 ; * * p<0.05$.

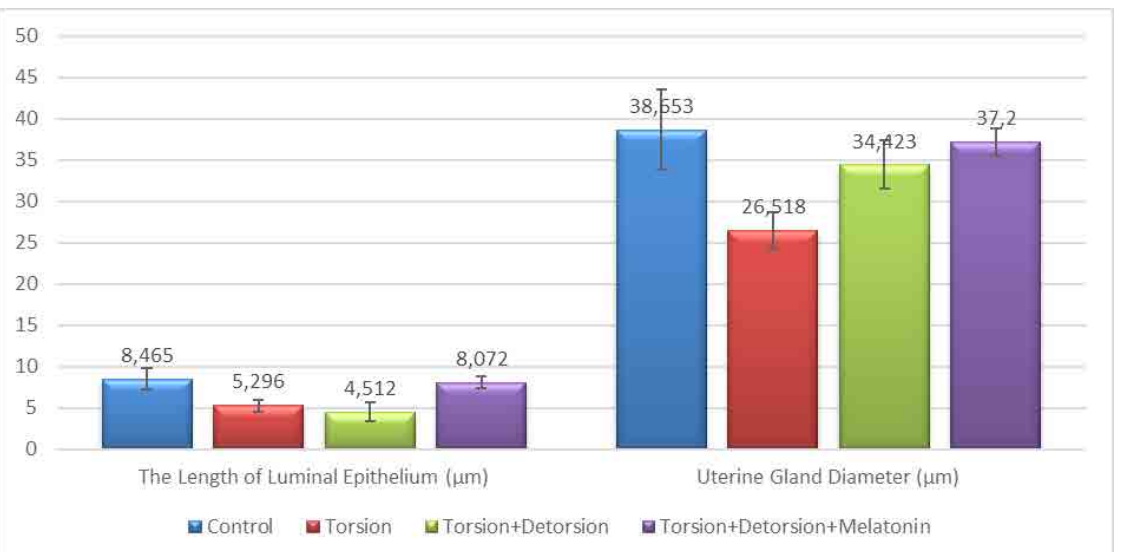

Figure 2 - Histogram showing the length of the uterine luminal epithelium and diameter of uterine glands in all groups.

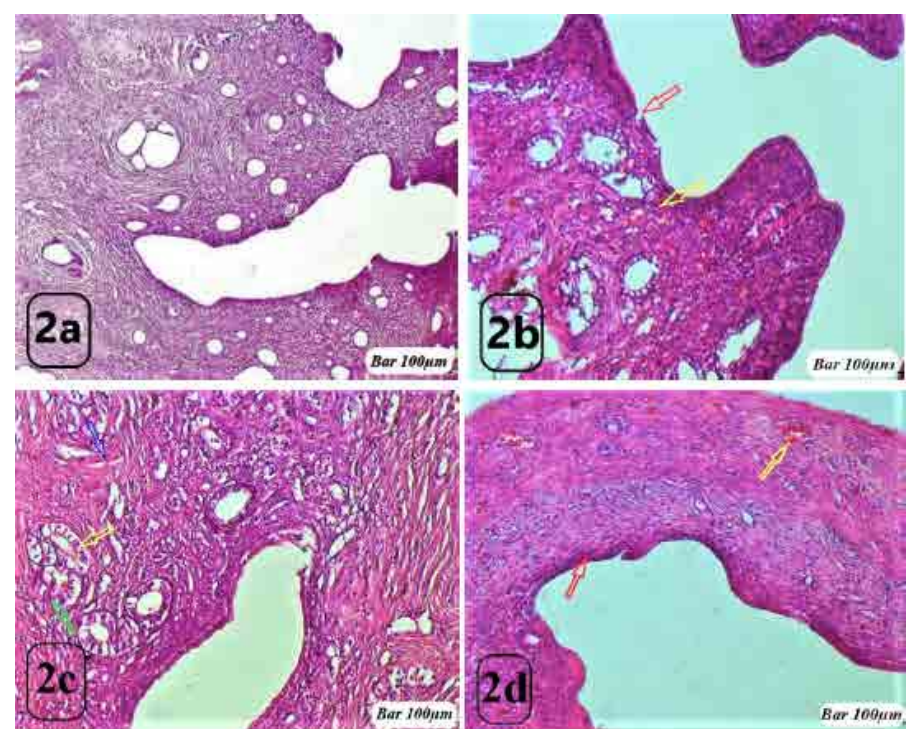

Figure 3 - a. Control Group. Normal appearance of the uterine mucosa HE staining, Bar $100 \mu \mathrm{m}$. b. Torsion Group. Uterine epithelial desquamation (red arrow), an increase in inflammatory cells in the lamina propria, vascular dilatation and hemorrhage, degeneration and apoptotic cells in the uterine glands (yellow arrow), HE staining, Bar 100 $\mu$ m. c. Torsion+Detorsion Group. Uterine epithelial desquamation (yellow arrow), lamina propria inflammation and edema (blue arrow, hemorrhage, vascular degeneration and apoptotic cells in the uterine glands (green arrow), HE staining, Bar 100 $\mu \mathrm{m}$. d. Torsion+Detorsion+Melatonin Group. Regular cylindrical epithelium (red arrow), mild hemorrhage in small vessels of lamina propria (yellow arrow), in view close to normal cells in the uterine glands, HE staining. Bar $100 \mu \mathrm{m}$. 

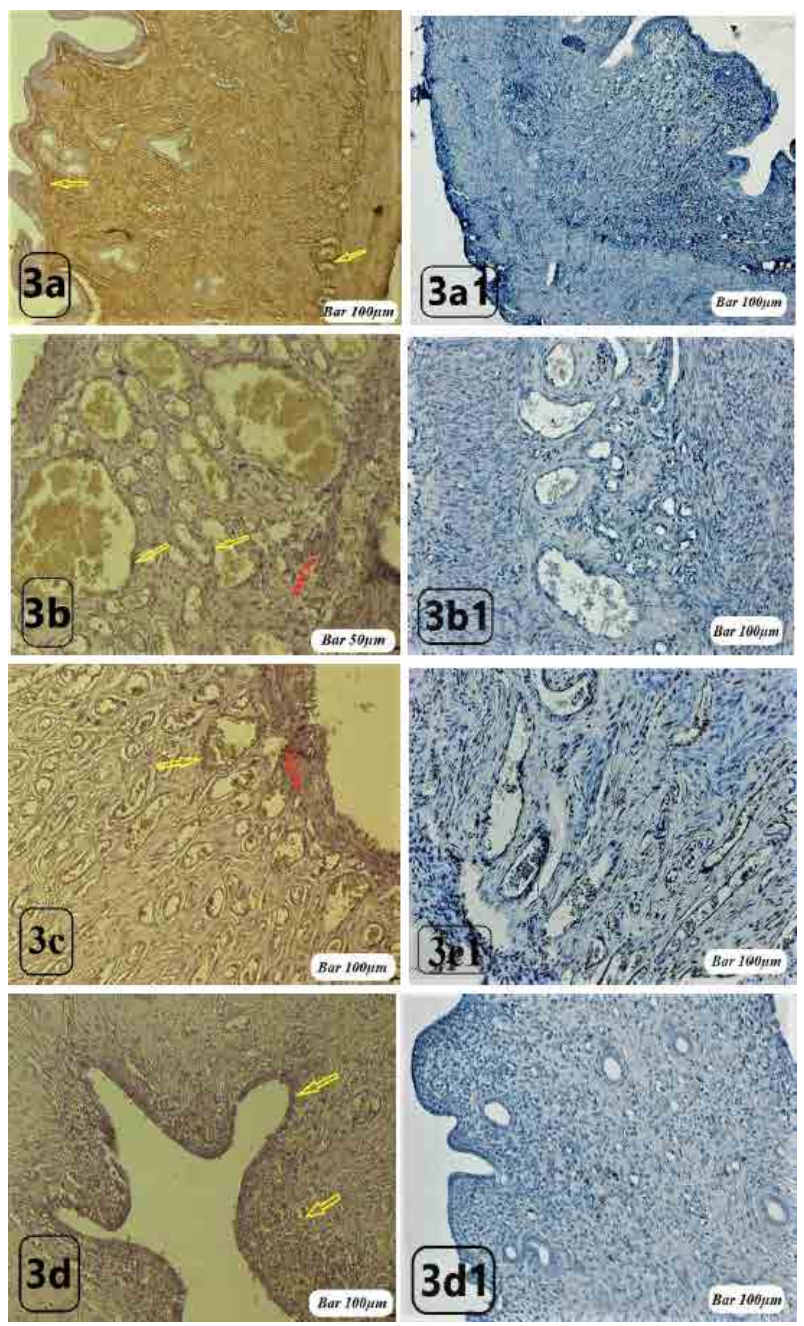

Figure 3 - a. Control Group. VEGF staining in the control group. VEGF positive expression in Endometrial stromal cells, and endothelial cells (yellow arrow).VEGF immunstaining, Bar 100 $\mu \mathrm{m}$. a1. Negative control, Hematoxylene staining, Bar $100 \mu \mathrm{m}$, b. Torsion Group. Immunolocalization of VEGF in rat uterus during the torsion, endometrial and myometrial increased VEGF in vascular endothelial cells (yellow arrow),VEGF positive expression in inflammatory cells in connective tissue area (red arrow). VEGF immunstaining, Bar $50 \mu \mathrm{m}$. b1. Negative control, Hematoxylene staining, Bar $100 \mu \mathrm{m}$. c. Torsion+Detorsion Group. In the bottom portion of the myometrium layer increased vascular endothelial and inflammatory cells in the VEGF (red arrow),VEGF immunstaining, Bar $100 \mu \mathrm{m}$. c1. Negative control, Hematoxylene staining, Bar $100 \mu \mathrm{m}$. d. Torsion+Detorsion+Melatonin Group. VEGF positive reaction in endometrial epithelium cells and endothelial cells in stromal area (yellow arrow), VEGF immunstaining, Bar $100 \mu \mathrm{m}$. d1.

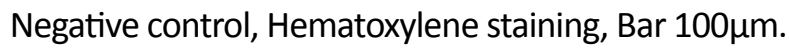
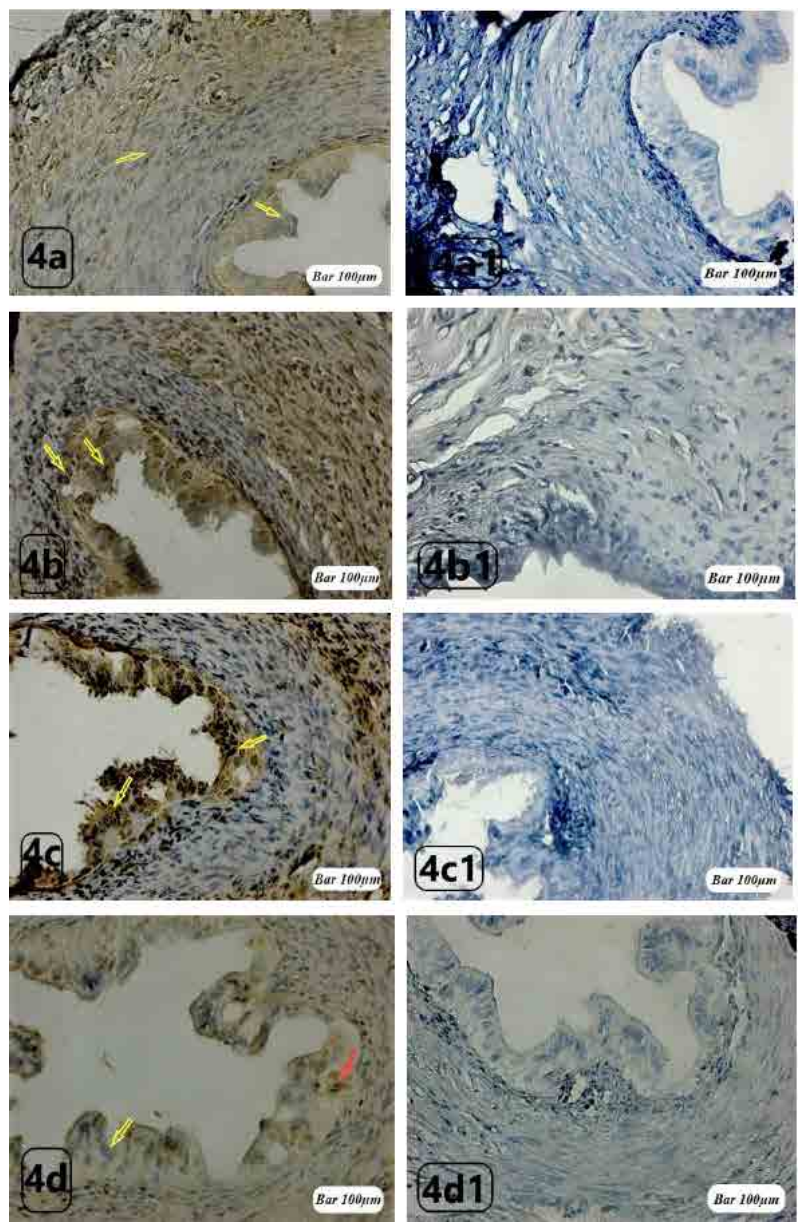

Figure 4 - a. Control Group. Endometrial and myometrial cells $\mathrm{Bcl} 2$ mild positive expression (yellow arrow), Bcl2 immun-staining, Bar $100 \mu \mathrm{m}$. a1. Negative control, Hematoxylene staining, Bar $100 \mu \mathrm{m}$. b. Torsion Group. Apoptotic changes in cells of the uterine epithelium and stromal cells, Bcl2 positive cells (yellow arrow), Bcl2 immun-staining, Bar $100 \mu \mathrm{m}$. b1. Negative control, Hematoxylene staining, Bar $100 \mu \mathrm{m}$. c. Torsion+Detorsion Group. Apical epithelial and some stromal cells, Bcl2-positive cells (yellow arrow), Bcl2 immun-staining, Bar $100 \mu \mathrm{m}$. c1. Negative control, Hematoxylene staining, Bar $100 \mu \mathrm{m}$. d. Torsion+Detorsion+Melatonin Group. $\mathrm{Bcl} 2$ negative expression in endometrial epithelium (yellow arrow), Bcl2 positive reaction in the cells around uterinal glands (red arrow), $\mathrm{Bcl} 2$ immun-staining, Bar $100 \mu \mathrm{m}$. d1. Negative control, Hematoxylene staining, Bar $100 \mu \mathrm{m}$.

\section{Histological findings}

The morphologic characteristics of the uterus tissues were normal in the control group. 
The uterus from sham operation group were normal in histopathological appearance.In the torsion group; Light microscopic examination of cervical degeneration mostly occupied endometrial uterine lumen and the lamina propria, revealed the significant proliferation. An increase in inflammatory cells in the lamina propria, vascular dilatation and hemorrhage, degeneration and apoptotic cells in the uterine glands was observed. Lamina propria and between the muscle layer showed a dilatation and hemorrhage increase in irregular veins. In the ovariectomized rats, reductions in the sizes of both the uterine epithelium and the endometrial glands were observed, as well as a loss of connective tissue.

\section{Immunohistochemical findings}

In the torsion group, increased VEGF expression in vascular endothelial and inflammatory cells. Torsion and detorsion group showed VEGF-positive reaction. In torsion group , the apoptotic cells increased in luminal epithelium and gland cells. Apoptotic $\mathrm{Bcl} 2$ cells were stained as positive. Bcl2 negative expression in endometrial epithelium, Bcl2 positive reaction showed in the cells around uterinal glands. In the uterine epithelium, it was observed in the protection effect of melatonin.

\section{- Discussion}

The present experimental study aimed to investigated whether melatonin administration is useful or not in the prevention of endometrial damage subjected to ovarian torsion in rats followed by the histological, immunohistochemical and western blotting analysis. For the preservation of the ovarian function, it is important that the ovarian torsion and subsequent detorsion be done surgically quickly. Detoxification applied to protect the ovaries leads to biochemical and histopathological changes in the ovarian tissue. Because ovaries do not determine the degree of ischemia in the intraoperative procedure, detorsion is recommended as conservative treatment in all patients with ovarian torsion ${ }^{35}$.

Ovarian torsion causes congestion, arterial thrombosis and necrosis. Blood flow to the ovaries is supplied through the vascular structures on the supportive tissues and the torsion occludes these vascular structures, leading subsequently to ischemic damage on the ovarian cells ${ }^{36}$. Murray et al. ${ }^{37}$ showed that OVX reduces the cell heights of the luminal and glandular epithelium in the sheep uterus. They also demonstrated that these changes are ameliorated by the coadministration of estrogen and progesterone after ovariectomy. Melatonin is a broad-spectrum antioxidant and therefore may interfere with the oxidative stress seen in endometriosis ${ }^{38}$. Melatonin is a powerful antioxidant with a influence on the endogenous antioxidant system. Concurrently, melatonin administration decreases lipid peroxidation and increases the levels of antioxidants ${ }^{39}$. MDA is a secondary product of oxidative stress formed during lipid peroxidation and is significantly increased by ischemia-reperfusion injury. Melatonin also has an antiadhesive effect and decreases leukocyte-mediated endothelium injury $^{20}$. The examination of the uterus for rat ovarectomized showed a degeneration in uterine glands; dilation of blood vessels in the internal layer with a thrombosis and bleeding; abnormal nucleuses and vacuolated cytoplasm above and below the nucleus

VEGF has direct autocrine or paracrine effects on the luminal epithelial cells of the uterus during endometrial repair in the macaque monkey and mice ${ }^{40,41}$. Alterations in the expression of VEGF and its receptors are associated with disruption of ovarian and uterine functions ${ }^{42}$. In a study in mice, endometrial expression of VEGF mRNA changed throughout the estrous cycle, shifting from the luminal epithelium during the proliferative phase to 
the luminal stroma during the secretory phase, again indicating that ovarian steroids modulate endometrial VEGF expression ${ }^{43}$. Damous et al. ${ }^{44}$ have investigated the safety and efficacy of treatment of adipose tissue stem cells (ASCs) in newly vaccinated ovaries 30 days after the injection. They found that the estrogen phase started earlier in the grafted ovaries treated with rat ASCs obtained from transgenic mice that overexpress the green fluorescent protein $(p<0.05)$. And they also observed that increased VEGF-A expression (11-fold in grafted ovaries and 5-fold in topic ovaries vs. control) and an increased number of blood vessels $(p<0.05)$ in ovarian tissue without leading to apoptosis or cellular proliferation $(p>0.05)$. In the torsion group in our study, the endometrium and myometrium vascular endothelial cells in the VEGF showed positive reaction.VEGF showed a significant increase in inflammatory cells. In detorsion group, torsion VEGF expression showed more regular distribution of the group, while in the melatonin group showed VEGFpositive reaction in the small blood vessels in the endometrium.It is an important marker on a powerful endothelial mitogen VEGF angiogenesis regulation.We suggest that VEGF are a regulator of the microvascular response of the endometrium

Sapmaz-Metin et al. $^{45}$ observed apoptotic cell number increased significantly in ovaries after IR. An experimental IR study of Yigiter et al. $^{46}$ showed that the apoptotic cell number increased after ischemia but decreased significantly in a growth hormone treatment group. Ferreira et al. ${ }^{47}$ have reported that melatonin affects the mechanism and reduces the apoptosis of the uterus of rats exposed to continuous light. After the administration of melatonin, they observed the regulation of important anti-apoptotic genes such as Api5, Aven and $B c / 2$. In according to their result, these genes support the results of DNA fragmentation by the TUNNEL analysis method and they suggested that melatonin influences the mechanism of apoptosis. In our study, apoptosis was evaluated by $\mathrm{Bcl} 2$ and Western blot analysis. In the torsion group, apoptotic cells increased in the uterine epithelium. In the melatonin group showed that the $\mathrm{Bcl} 2$ negative effect on the uterine epithelium and did not lead to apoptotic cells. Melatonin inhibition of cellular apoptosis by ischemia/reperfusion has been an effect on the uterine tissue.

In the torsion+detorsion group, significant damage was observed in endothelial cell damage in the deteriorating vessel wall. It was also found that basal membrane structure deteriorated and inflammatory cell infiltration increased. It was found that the basal membrane structure was organized in the melatonin-treated group, the endothelial cells were composed of the normal appearance and the flat nuclei. As shown in the immunohistochemical and Western blot analyses, an increase in VEGF expression resulted in the rearrangement of endothelial cell growth and the induction of angiogenesis. Apoptotic changes were decreased in epithelial cells in endometrium, mitosis was increased in cells, $\mathrm{Bcl}-2$ expression was negative. $\mathrm{Bcl}-2$ expression was found to be positive in some uterinal glands located near the myometrium of the uterus. Depending on the effect of melatonin, apoptotic changes were observed in the cells of the surface epithelium, but apoptosis did not decrease with the positive expression of $\mathrm{Bcl}-2$ in the uterine glands.

\section{- Conclusion}

Melatonin-bearing receptors are induced by exposure of cells in uterine endometrial and myometrial layers to melatonin administration due to torsion and detorsion model. But, it was thought that the application of melatonin in the torsion-torsion models did not show the same characteristics in each layer of the uterus in terms of apoptosis and VEGF, Bcl-2 expressions in estrus phase. 


\section{References}

1. Qian J, Thomas AP, Schroeder AM, Rakshit K, Colwell CS, Matveyenko AV. Development of diabetes does not alter behavioral and molecular circadian rhythms in a transgenic rat model of type 2 diabetes mellitus. Am J Physiol Endocrinol Metab. 2017;313:E21321. PMID: 28465284. dol: 10.1152/ ajpendo.00406.2016.

2. Waly NE, Hallworth R. Circadian pattern of melatonin MT1 and MT2 receptor localization in the rat suprachiasmatic nucleus. J Circadian Rhythms. 2015;13:1. PMID: 27103927. doI: 10.5334/jcr.ab.

3. Kennaway DJ, Varcoe TJ, Voultsios A, Salkeld MD, Rattanatray L, Boden MJ. Acute inhibition of casein kinase $1 \delta / \varepsilon$ rapidly delays peripheral clock gene rhythms. Mol Cell Biochem. 2015;398:195-206. PMID: 25245819. dol: 10.1007/s11010-014-2219-8.

4. Castanho A, Bothorel B, Seguin L, Mocaër $E$, Pévet $P$. Like melatonin, agomelatine (S20098) increases the amplitude of oscillations of two clock outputs: melatonin and temperature rhythms. Chronobiol Int. 2014;31:371-81. PMID: 24328729. dol: 10.3109/07420528.2013.860457.

5. Anuradha, Krishna A. Prolactin modulates luteal activity in the short-nosed fruit bat, Cynopterus sphinxduring delayed embryonic development. Gen Comp Endocrinol. 2017;248:27-39. PMID: 28412388. dol: 10.1016/j.ygcen.2017.04.008.

6. Hirakawa T, Nasu K, Abe W, AoyagiY, Okamoto M, Kai K, Takebayashi K, Narahara H. miR503, a microRNA epigenetically repressed in endometriosis, induces apoptosis and cellcycle arrest and inhibits cell proliferation, angiogenesis, and contractility of human ovarian endometriotic stromal cells. Hum Reprod. 2016;31:2587-97. PMID: 27619772. doi: 10.1093/humrep/dew217.

7. Yildiz C, Kacan T, Akkar OB, Karakus S, Seker M, Kacan SB, Ozer H, Cetin A. Effect of imatinib on growth of experimental endometriosis in rats. Eur J Obstet Gynecol Reprod Biol. 2016;197:159-63. PMID: 26773307. doi: 10.1016/j.ejogrb.2015.12.013.

8. Delbandi AA, Mahmoudi $M$, Shervin A, Zarnani AH. 1,25-Dihydroxy vitamin D3 modulates endometriosis-related features of human endometriotic stromal cells. Am
J Reprod Immunol. 2016;75:461-73. PMID: 26691009. doi: 10.1111/aji.12463.

9. Tsuzuki T, Okada H, Shindoh H, Shimoi K, Nishigaki A, Kanzaki H. Effects of the hypoxiainducible factor-1 inhibitor echinomycin on vascular endothelial growth factor production and apoptosis in human ectopic endometriotic stromal cells. Gynecol Endocrinol.2016;32:323-8.PMID:26654708. doi: 10.3109/09513590.2015.1121225.

10. Yildiz C, Kacan T, Akkar OB, Karakus S, Kacan $\mathrm{SB}$, Ozer $\mathrm{H}$, Cetin A. Effects of pazopanib, sunitinib, and sorafenib, anti-VEGF agents, on the growth of experimental endometriosis in rats. Reprod Sci. 2015;22:1445-51. PMID: 25963915. doi: $10.1177 / 1933719115584448$.

11.Ding D, Liu X, Duan J, Guo SW. Platelets are an unindicted culprit in the development of endometriosis: clinical and experimental evidence. Hum Reprod. 2015;30:812-32. PMID: 25740881. doi: 10.1093/humrep/ dev025.

12.Fan T, Pi H, Li M, Ren Z, He Z, Zhu F, Tian L, Tu M, Xie J, Liu M, Li Y, Tan M, Li G, Qing W, Reiter RJ, Yu Z, Wu H, Zhou Z. Inhibiting MT2-TFE3-dependent autophagy enhances melatonin-induced apoptosis in tongue squamous cell carcinoma. J Pineal Res. 2018;64. (Epub 2018 Jan 11). PMID: 29149494. doi: 10.1111/jpi.12457.

13.Goodarzi A, Zare Shahneh A, Kohram H, Sadeghi M, Moazenizadeh MH, FouladiNashta A, Dadashpour Davachi N. Effect of melatonin supplementation in the longterm preservation of the sheep ovaries at different temperatures and subsequent in vitro embryo production. Theriogenology. 2018;106:265-70. PMID: 29096275. doi: 10.1016/j.theriogenology.2017.10.009.

14.Sinha B, Wu Q, Li W, Tu Y, Sirianni AC, Chen Y, Jiang J, Zhang $X$, Chen W, Zhou S, Reiter RJ, Manning SM, Patel NJ, Aziz-Sultan AM, Inder TE, Friedlander RM, Fu J, Wang $X$. Protection of melatonin in experimental models of newborn hypoxic-ischemic brain injury through MT1 receptor. J Pineal Res. 2018;64. PMID: 28796402. doi: 10.1111/ jpi.12443.

15. Chen CH, Li CJ, Tai IC, Lin XH, Hsu HK, Ho ML. The fractionated toona sinensis leaf extract induces apoptosis of human osteosarcoma cells and inhibits tumor growth in a murine 
xenograft model. Integr Cancer Ther. 2017;16:397-405. PMID: 27879376. doi: $10.1177 / 1534735416675951$.

16.Ota H, Igarashi S, Hatazawa J, Tanaka T. Immunohistochemical assessment of superoxide dismutase expression in the endometrium in endometriosis and adenomyosis. Fertil Steril. 1999;72:129-34. PMID: 10428161.

17.Polak G, Koziol-Montewka M, Gogacz M, Tarkowski R, Kotarski J. Total antioxidant status of peritoneal fluid in infertile women. Europ J Obstet Gynecol Reprod Biol. 2001;94:261-3. PMID: 11165736.

18.Kanishi Y, Kobayashi Y, Noda S, Ishizuka B, Saito K. Differential growth inhibitory effect of melatonin on two endometrial cancer cell lines. J Pineal Res. 2000;28:227-33. PMID: 10831158.

19.Maestroni GJ. The immunoneuroendocrine role of melatonin. J Pineal Res. 1993;14:110. PMID: 8483103.

20.Schlabritz-Lutsevich N, Hellner N, Middendorf RD, Olcese J. The human myometrium as a target for melatonin. J Clin Endocrinol Metab. 2003;88:908-13. PMID: 12574232. doi: 10.1210/jc.2002-020449.

21.Zhao H, Pang SF, Poon A. mt(1) receptormediated antiproliferative effects of melatonin on the rat uterine anti mesometrial stromal cells. Mol Reprod Dev. 2002;61:192-9. PMID: 11803554. doi: 10.1002/mrd.1147.

22.Zhao H, Poon AM, Pang SF. Pharmacological characterization, molecular subtyping, and of putative melatonin receptors in uterine endometrium of estrous rats. Life Sci. 2000;66:1581-91. PMID: 11261588.

23.Dair EL, Simoes RS, Simões MJ, Romeu LR, Oliveira-Filho RM, Haidar MA, Baracat EC, Soares JM Jr. Effects of melatonin on the endometrial morphology and embryo implantation in rats. Fertil Steril. 2008;89:1299-305. PMID: 17561006. doi: 10.1016/j.fertnstert.2007.03.050.

24.Fuchs LF, Guimarães CR, Maganhin CC, Simões RS, Baracat MC, Soares Júnior JM, Baracat EC. Melatonin action in apoptosis and vascular endothelial growth factor in adrenal cortex of pinealectomized female rats. Rev Bras Ginecol Obstet. 2010;32:37480. PMID: 21180873.

25.Soares JM Jr, Simões MJ, Oshima CT, Mora
OA, De Lima GR, Baracat EC. Pinealectomy changes rat ovarian interstitial cell morphology and decreases progesterone receptor expression. Gynecol Endocrinol. 2003;17:115-23. PMID: 12737672.

26.Romeu LR, da Motta EL, Maganhin CC, Oshima CT, Fonseca MC, Barrueco KF, Simões RS, Pellegrino R, Baracat EC, Soares-Junior JM. Effects of melatonin on histomorphology and on the expression of steroid receptors, VEGF, and PCNA in ovaries of pinealectomized female rats. Fertil Steril. 2011;95:1379-84. PMID: 20605140. doi: 10.1016/j.fertnstert.2010.04.042.

27. Neufeld G, Tessler S, Gitay-Goren H, Cohen T, Levi BZ. Vascular endothelial growth factor and its receptors. Prog Growth Factor Res. 1994;5:89-97. PMID: 7515293.

28.Senger DR, Van de Water L, Brown LF, Nagy JA, Yeo KT, Yeo TK, Berse B, Jackman RW, Dvorak AM, Dvorak HF. Vascular permeability factor (VPF, VEGF) in tumor biology. Cancer Metastasis Rev. 1993;12:303-24. PMID: 8281615.

29.Armstrong JS. Mitochondria: a target for cancer therapy. $\mathrm{Br} J$ Pharmacol. 2006; 147:239-48. PMID: 16331284. doi: 10.1038/ sj.bjp.0706556.

30.Reed JC. Bcl-2 and the regulation of programmed cell death. J Cell Biol. 1994;124:1-6. PMID: 829449.

31.Lu QL, Abel P, Foster CS, Lalani EN. Bcl2: role in epithelial differentiation and oncogenesis. Hum Pathol. 1996;27:102-10. PMID: 8617450.

32. Karaca M, Odabasoglu $F$, Kumtepe $Y$, Albayrak A, Cadirci E, Keles ON. Protective effects of erythropoietin on ischemia/ reperfusion injury of rat ovary. Eur J Obstet Gynecol Reprod Biol. 2009;144:15762. PMID: 19375213. doi: 10.1016/j. ejogrb.2009.03.011.

33. Mahmood T, Yang PC. Western blot: technique, theory, and trouble shooting. N Am J Med Sci. 2012;4:429-34. PMID: 23050259. doi: 10.4103/1947-2714.100998.

34.Jia YF, Gao HL, Ma LJ, Li J. Effect of nimodipine on rat spinal cord injury. Genet Mol Res. 2015;14:1269-76. PMID: 25730065. doi: 10.4238/2015. February.13.5.

35. Huang C, Hong MK, Ding DC. A review of ovary torsion. Ci Ji Yi Xue Za Zhi. 2017;29:143-7. PMID: 28974907.doi: 10.4103/tcmj.tcmj_55_17. 
36.Oelsner G, Shashar D. Adnexal torsion. Clin Obstet Gynecol. 2006;49:459-63. PMID: 16885653.

37.Murray MK. The effect of estrogen and progesterone on structural changes in the uterine glandular epithelium of the ovariectomized sheep. Biol Reprod. 1992;47:408-17. PMID: 1511094.

38. Reiter RJ, Tan DX, Maldonado MD. Melatonin as an antioxidant: physiology versus pharmacology. J Pineal Res. 2005;39:2156. PMID: 16098101. doi: 10.1111/j.1600079X.2005.00261.x.

39.Liu Y, Shimizu I, Omoya T, Ito S, Gu XS, Zuo J. Protective effect of estradiol on hepatocytic oxidative damage. World J Gastroenterol. 2002;8:363-6. PMID: 11925626.

40.Nayak NR, Brenner RM. Vascular proliferation and vascular endothelial growth factor expression in the rhesus macaque endometrium. J Clin Endocrinol Metab. 2002;87:1845-55. PMID: 11932329. doi: $10.1210 /$ jcem.87.4.8413.

41.Fan X, Krieg S, Kuo CJ, Wiegand SJ, Rabinovitch $\mathrm{M}$, Druzin ML, Brenner RM, Giudice LC, Nayak NR. VEGF blockade inhibits angiogenesis and re-epithelialization of endometrium. FASEB J. 2008;22:3571-80. PMID: 18606863. doi: 10.1096/fj.08-111401.

42.Ferrara N, Gerber HP, LeCouter J. The biology of VEGF and its receptors. Nat Med. 2003;9:669-76. PMID: 12778165. doi: 10.1038/nm0603-669.

43.Shweiki D, Itin A, Neufeld G, Gitay-Goren $H$, Keshet E. Patterns of expression of vascular endothelial growth factor (VEGF) and VEGF receptors in mice suggest a role in hormonally regulated angiogenesis. J Clin Invest. 1993;91:2235-43. PMID: 7683699. doi: $10.1172 / J C I 116450$.

44.Damous LL, Nakamuta JS, Carvalho AE, Carvalho KC, Soares JM Jr, Simões Mde J, Krieger JE, Baracat EC. Does adipose tissue-derived stem cell therapy improve graft quality in freshly grafted ovaries? Reprod Biol Endocrinol. 2015;13:108. PMID: 26394676. doi: 10.1186/s12958-015-0104-2.

45.Sapmaz-Metin M, Topcu-Tarladacalisir Y, Uz $\mathrm{YH}$, Inan M, Omurlu IK, Cerkezkayabekir A, Kizilay G, Akpolat M. Vitamin E modulates apoptosis and c-jun $\mathrm{N}$-terminal kinase activation in ovarian torsion-detorsion injury Exp Mol Pathol. 2013;95:2139. PMID: 23911905. doi: 10.1016/j. yexmp.2013.07.007.

46.Yigiter M, Halici Z, Odabasoglu F, Keles ON, Atalay F, Unal B, Salman AB. Growth hormone reduces tissue damage in rat ovaries subjected to torsion and detorsion: biochemical and histopathologic evaluation. Eur J Obstet Gynecol Reprod Biol. 2011;157:94-100. PMID: 21439711. doi: 10.1016/j.ejogrb.2011.02.012.

47.Ferreira CS, Carvalho KC, Maganhin CC, Paiotti AP, Oshima CT, Simões MJ, Baracat $E C$, Soares JM Jr. Does melatonin influence the apoptosis in rat uterus of animals exposed to continuous light? Apoptosis. 2016;21:155-62. PMID: 26542995. doi DOI: 10.1007/s10495-015-1195-0.

\section{Correspondence:}

Prof. Engin Deveci

Phone: +90 4122488001 Ext. 4443 (Faculty

room)

Fax: +904122488440

devecie32@hotmail

Received: Mar 20, 2018

Review: May 22, 2018

Accepted: June 21, 2018
Conflict of interest: none

Financial source: none 